\title{
Prevalence and Risk Factors of Hepatitis B Virus Genotype D Amongst Inmates in Alborz Province, Iran: A Cross-Sectional Survey
}

\author{
Fatemeh Salem ${ }^{1}$, Soheila Hekmat ${ }^{1, *}$, Mohammad Reza Aghasadeghi ${ }^{1}$, Foozieh Javadi ${ }^{1}$, Hos- \\ sein Gholami ${ }^{2}$, Ehsan Mostafavi ${ }^{3}$ \\ ${ }_{2}^{1}$ Department of Hepatitis and AIDS, Pasteur Institute of Iran, Tehran, IR Iran \\ 2 Executive deputy of health reference laboratory, Tehran, IR Iran \\ ${ }^{3}$ Department of Epidemiology, Pasteur institute of Iran, Tehran, IR Iran \\ *Corresponding author: Soheila Hekmat, Department of Hepatitis and AIDS, Pasteur Institute of Iran, Tehran, IR Iran. Tel/Fax:+98-2166969291, E-mail: sh_hekmat@yahoo.com.
}

Received: January 10, 2013; Revised: May 16, 2013; Accepted: May 21, 2013

\begin{abstract}
Objectives: The aim of the present study was to determine the rate, risk factors and genotypes of Hepatitis B virus amongst imprisoned men as a high-risk subpopulation.

Patients and Methods: This study was an anonymous cross-sectional study conducted on 3000 sentenced men in Karaj jails from 1 December 2008 to 28 November 2009. HBV serological markers [hepatitis B surface antigen (HBsAg) and hepatitis B e antigen (HBeAg)], human immunodeficiency virus antibody (anti-HIV)and hepatitis C antibody (anti-HCV) were analyzed by the ELISA technique. Nested PCR was done for the detection of HBVDNA and patterns of restriction fragment length polymorphisms (RFLP) were obtained to determine the HBV genotypes. These patterns were confirmed by direct sequencing.

Results: Hepatitis B surface antigen (HBsAg) was found in 122/3000 (4.1\%) prisoners. Hepatitis B e antigen (HBeAg), anti-HIV, anti-HCV and anti-HIV/anti-HCV were detected in 52/122 (42.6\%), 12/122 (10\%), 22/122 (18\%) and 3/122 (2.4\%) prisoners, respectively. The HBV-DNA was found in 115/122 (94.3\%) prisoners. The most high risk behavior was to utilize the collaborative syringe by injecting drug users (IDUs) with or without other risk factors (75.3\%). Genotype D1 was obviously the only predominant type (100\%).

Conclusions: The rate of $\mathrm{HBV}$ in prisoners was significantly higher than that reported for the general population (4.1\%vs. $<2 \%$ ). Blood borne viral co-infections were prevalent in HBsAg positive prisoners. Continual tracing of genotypes and risk factors are helpful for identifying transmission patterns and target at-risk groups for preventive programs. High rates of HBV in prisoners indicates the need for extensive free of charge vaccination of this subpopulation. Hepatitis B is the most serious type of viral hepatitis infection. It can cause chronic liver disease and puts people at a high risk of death from cirrhosis of the liver and liver cancer. Worldwide, about two billion people have been infected with the hepatitis B virus (HBV) and more than 240 million have chronic (long-term) liver infections. About 600,000 people die every year from this serious infection. Unfortunately, high rate of intravenous drug use, high-risk sexual behaviors and overcrowding have increasingly made prisons a breeding ground for hepatitis B infection.
\end{abstract}

Keywords: Hepatitis B Virus; Injecting Drug Users; Prisoners

\section{Background}

In spite of routine hepatitis B immunization, because of negligence in the performance of vaccination of high risk unvaccinated adults, this infection is still a leading cause of liver cirrhosis and hepatocellular carcinoma (HCC). These complications play a leading role in morbidity and mortality worldwide $(1,2)$. According to different studies, the rate of hepatitis B virus (HBV) carriers varies widely from $0.1 \%$ to $20 \%$ around the world. Prevalence of HBV has remarkably declined in the Iranian population during the two last decades (3). Seroprevalence of Hepatitis B surface antigen (HBsAg) has changed from 2.5-7\% in 1980 s to $1.07-5 \%$ in 1990 s and1-2\% in 2000 . Fortunately hepatitis B infection has recently classified as having low endemicity $(4,5)$.

Eight major genotypes (A-H) with several subtypes and two additional isolated genotypes (genotype I in Vietnam and genotype J in Japan) are defined by insertions or deletions of nucleotides, but with less than $10 \%$ overall variation among them (6-8). Genotyping of HBV isolates from different parts of the world have shown a distinct geographical distribution even within a region. Genotypes are proving to be an invaluable tool in tracing spread of hepatitis B virus and establishing HBV origins in different parts of the world (9). The molecular epidemiology of HBV has been reported for the Iranian general population. Genotype D has almost been the only type of HBV with high genetic homogeneity in this country (10). 
Previous studies have revealed that HBV infection is more prevalent in prisoners. The overall prevalence of HBV infection ranges between $1.8 \%$ and $62 \%$ among adult inmates. High rates of intravenous drug use, high risk sexual behaviors, sharing close living quarters with other infected inmates and overcrowding have increasingly made prisons a proper environment for blood-borne infections (11-13). Intravenous drug use by inmates because of sharing of drug-preparation equipment, needle-sharing, reused syringes and other risky behaviors (e.g. unsafe sex, homosexuality, tattooing, etc.) are a well known route of $\mathrm{HBV}$ and other blood- borne infectious agents and exposure to hepatitis B virus is common in injecting drug users (IDUs) $(14,15)$. Based on Iranian Welfare Organization reports, there are 1.8 million drug users in Iran, and more than 9 to16 percent of them are injecting drug users, while half share needles. Thus, it can be estimated that the IDU population in Iran ranges between 200,000 and 300,000. Unfortunately IDUs are growing in number in Iran and remain an important health problem $(16,17)$.

\section{Objectives}

The aim of this study was to determine the rate, risk factors and genotypes of hepatitis B virus amongst imprisoned men as a high-risk subpopulation.

\section{Patients and Methods}

\subsection{Serum Samples}

In a cross-sectional study conducted from 1 December 2008 to 28 November 2009, serum samples were collected from three thousand male prisoners in three prisons of Alborz province (Ghezel Hessar, RajaiiShahr and Nedamatgah Karaj). Serum samples were stored at $-80^{\circ} \mathrm{C}$ until tested. HBsAg positive inmates were eligible and convoked for interviews using a questionnaire including demographic characteristics such as age, education level, family size and some important risk factors as depicted in Table 1.

\subsection{Ethical Considerations}

The study was revised and approved by the Pasteur Institute of Iran Reviewer Board. Thorough discussions took place with collaboration of the prison authorities. The information sheets were submitted to inmates upon description of the study in layman's terms.

\subsection{Serological Analysis}

All HBsAg positive samples were tested for hepatitis B e antigen (HBeAg), anti hepatitis C virus (anti-HCV), and anti HIV with commercial third generation ELISA kits (Dia
Pro Diagnostic Bioprobes, Srl., Italy) based on the manufacturers descriptions. All cases with cut-off values more than 1 were considered as positive.

\subsection{Nested PCR and RFLP}

HBV-DNA was extracted from $200 \mu \mathrm{l}$ of serum using High Pure Viral Nucleic Acid Kit (Roche, Diagnostics $\mathrm{GmbH}$, and Manheim, Germany) according to the manufacturers instructions. RT-PCR and RFLP were performed using the type-specific primers and methods described previously by Zeng et al (18).

To investigate the HBV genotypes, partial HBV $S$ open reading frame (ORF) (585bp) was chosen for amplification with specified primers: OHBV-F, 5-GGGACACCATATTCTTGG-3́ positions 2820-2837 nt and O-HBV-R, 5-TTAGGGTTTAAATGTATACCCA-3́ position $842-821 \mathrm{nt}$ as the outer primers and I-HBV-F, 5-GCGGGGTTTTTCTTGTTGA-3 positions 203-221 nt and IHBV-R, 5-GGGACTCAAGATGTTGTACAG-3́ position 787-767 nt as the inner primers. Nested-PCR was performed for amplification of this S segment. The second-round PCR product was mixed with chosen restriction endonuclease digestion enzymes: BsrI, StyI, DpnI, EaeI, HpaII (Fermentas GmbH, Germany).

\subsection{DNA Sequencing and Phylogenetic Analysis}

The second round PCR products were purified using a High Pure PCR product purification kit (Roche, Diagnostics $\mathrm{GmbH}$ ) and sequenced directly at the SEQLAB- Gottingen $\mathrm{GmbH}$, Germany, using the inner primers (I-HBV-F). Identified sequences were compared with a set of published sequences corresponding to all HBV genotypes (A-H), obtained from GenBank at the NCBI. Nucleotide sequences were aligned with Clustal X program using the Bio Edit software (The Bio Edit Sequence Alignment Editor software, North California State University) and confirmed by visual inspection. Genetic distances were estimated using Kimura two parameter matrixes (19) and phylogenetic tree was constructed by the neighborjoining method. The analysis and calculated nucleotide differences within and between the isolate sequences were carried out by the MEGA program version $4(20,21)$.

\subsection{Statistical Analysis}

Statistical analysis was performed using the SPSS software version 16 and the significance level was set at $P$ value $<0.05$. Quantitative variables were expressed as means and standard deviations, whereas qualitative variables were expressed as percentages. The Student's t test and chi-square $\left(\chi^{2}\right)$ test were used to check the differences between means and percentages, respectively. 
Salem F et al.

Table 1. Distribution of Frequency of HBsAg Positive Prisoners According to Variables, P value $<0.05$ Level

\begin{tabular}{|c|c|}
\hline Variables & HBsAg Pos ${ }^{\mathrm{a}}$, No. (\%) \\
\hline HBeAg Pos & $52(42.6)$ \\
\hline HBeAg Neg ${ }^{\mathrm{a}}$ & $70(57.4)$ \\
\hline Total & $122(100)$ \\
\hline \multicolumn{2}{|l|}{ Age, y } \\
\hline $20-24$ & $1(8)$ \\
\hline $25-29$ & $16(13)$ \\
\hline $30-34$ & $45(36.6)$ \\
\hline $35-39$ & $28(22.8)$ \\
\hline $40-44$ & $11(8.9)$ \\
\hline$>45$ & $21(17.9)$ \\
\hline Total & $122(100)$ \\
\hline \multicolumn{2}{|l|}{ Risk Factors } \\
\hline $\mathrm{IDU}^{\mathrm{a}}$ & $51(41.8)$ \\
\hline $\mathrm{IDU}+\mathrm{MSP}^{\mathrm{a}}$ & $40(32.7)$ \\
\hline $\mathrm{IDU}+\mathrm{MSP}+\mathrm{BT}^{\mathrm{a}}$ & $1(0.8)$ \\
\hline Hemodialysis & $13(10.7)$ \\
\hline Unknown & $17(14)$ \\
\hline Total & $122(100)$ \\
\hline \multicolumn{2}{|l|}{ Education Level } \\
\hline Illiterate & $20(16.3)$ \\
\hline Primary & $36(29.5)$ \\
\hline Middle school & $34(28)$ \\
\hline High school & $9(7.3)$ \\
\hline Diploma & $21(17.2)$ \\
\hline Junior collage & $2(1.7)$ \\
\hline Total & $122(100)$ \\
\hline \multicolumn{2}{|l|}{ Family Size } \\
\hline 1-2, Low & $24,(20)$ \\
\hline 3-5, Medium & $32,(26)$ \\
\hline $6-9$, high & $66,(54)$ \\
\hline Total & $122,(100)$ \\
\hline \multicolumn{2}{|l|}{ Co Infection } \\
\hline Anti-HCV Pos & $22(18)$ \\
\hline Anti-HIV Pos & $12(10)$ \\
\hline Anti-HCV+Anti-HIV & $3(2.4)$ \\
\hline Total & $122(100)$ \\
\hline
\end{tabular}

a Abbreviations: Pos, Positive; Neg, Negative; IDU, Intravenous Drug User; MSP, Multiple Sexual Partners; BT, Blood Transfusion.

\section{Results}

Out of the total 3000 imprisoned men, 122 (4.1\%) were found to be seropositive for HBsAg. Some demographic characteristics (age, level of education, family size) and risk factors of HBsAg positive prisoners are stated in Table 1. The mean age was 34.6 with a standard deviation of
5.8 years. IDU was solely the most important risk factor amongst HBsAg positive prisoners 51/122 (41.8\%); in comparison to IDU with sexual contact 40/122 (32.7\%) and haemodialysis 13/122 (10.7\%). However, the greatest number of HBsAg-positivity was observed in IDUs with or without suspicious sexual contact or blood transfusion 92/122 
(75.3\%), where 70\% didn ${ }^{-} t$ have high level of education (Table 1). On the basis of the serological status the rate of HBeAg, anti HCV and anti HIV are presented in Table 1.

The HBV-DNA was detected in 115/122 (94.3\%) of HBsAg positive samples by nested PCR. All HBV DNA positive samples (115/115 (100\%)) were analyzed on the basis of RFLP patterns by digestion of the $S$ region (nt 203 to $n t$ 787), to determine all HBV genotypes. DpnIenzymatic digestion of nt 491 produced $289 \mathrm{bp}$ and $296 \mathrm{bp}$ fragments and was recognized as genotype D in all HBV- DNA positive samples (Figure 1).

Figure 1. RFLP Analysis Using Nested PCR of HBV S Amplicon and Digestion Enzymes

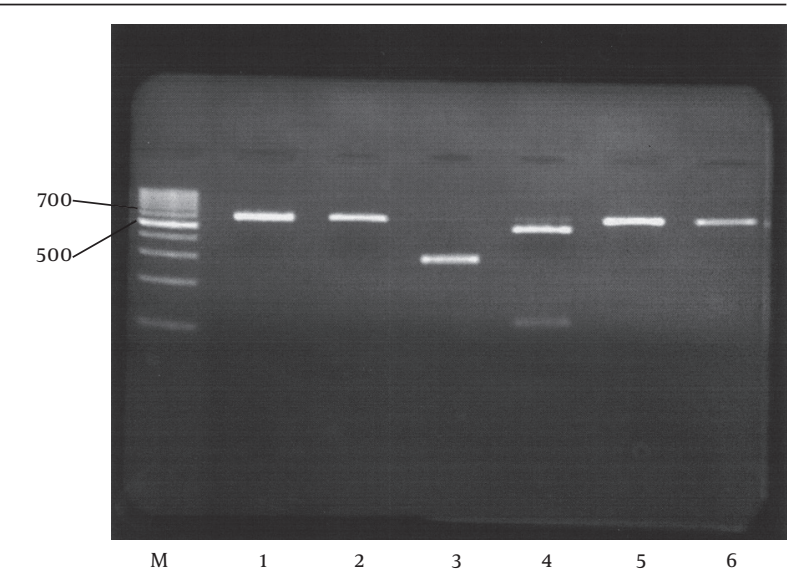

M: 100 bp DNA marker; Lane1: Non enzymatic degradation by Styl and Bsrl showed genotype D, F, H. DpnI. Enzymatic degradation of 491 nt produced 289 and 296 nt fragments; recognized as genotype D.

The sequences of 12 random samples were evaluated by RFLP and compared with reference sequences of HBV obtained from Gene Bank database using the N-J method for phylogenetic analysis. Direct sequencing of the ORF $S$ and phylogenetic tree confirmed that the results were deducted by the RFLP technique and all the isolates clustered within genotype D1 (subtype ayw) (Figure 2).

\section{Discussion}

This study provided basic information about the HBV positivity rate, risk factors and genotype distribution among Iranian prisoners and will be valuable for future studies on distribution patterns and precautionary programs of HBV infection. Even though during the last decade Iran has been classified as having low endemicity (1\%) for hepatitis B infection (5), but the prevalence of $\mathrm{HBV}$ in some risky regions such as prisons is significantly higher than that reported from the general population; as in this study, the sero prevalence of HBsAg was found to be 122 / 3000 (4.1\%) for imprisoned individuals ( $\mathrm{P}=$
0.0001). The highest frequency of HBsAg was found for the age group of 30 to 40 years where more than $74 \%$ had not completed their high school education. Moreover, poor knowledge is a potential reason for unawareness about risk factors and transmission modes. Most HBsAg cases (66/122 (54\%)) had lived in large families (6 - 9 family size). They seemed tohave been suffering from low socioeconomic status.

In the present study, the greatest rate of HBV was found for injecting drug users 92/122 (75.3\%) where about 51/122 (41.8\%) had no other specific risk factors. There was a strong association between injection drug use and blood born diseases. In this manner, a large number of HBV infections in north-western Europe, USA and Middle East (such as Iran) are transmitted horizontally (22) while the main route of transmission in Southeast Asia remains vertical (23). Our results have showed that there was a direct relationship between incarceration and blood borne virus co-infections.

The HBV/HCV (18\%), HBV/HIV (10\%) and HBV/HIV/HCV (2.4\%) infections used to be prevalent among prisoners especially in IDUs. These findings are in agreement with Sofian et al. findings, which showed that hepatitis-HIV serum markers were prevalent in IDUs of some central cities of Iran (24). Here of, drug addiction not only weakens the immune system but is also linked with risky behaviors. All these outcomes were able to demonstrate that intravenous injection drug use is a key risk factor for HIVhepatitis co-infection in our prisons.

Determining the genotypes of hepatitis B virus provides epidemiological data, which can affect vaccination and antiviral treatment strategies, improvement of diagnostic criteria and prediction of the course of the disease (25, 26). This study showed that genotype D (sub genotype D1, subtype ayw) was the only detectable genotype in the studied prisoners. Our results are in accordance with that of Norder et al. who showed that although genotype D is the most widespread but sub genotype D1 occurs mainly in the Middle East (27). According to this study, genotype D1 is mostly transmitted by intravenous drug use. Sexual contact and hemodialysis arethe second and third most frequent forms of transmission, respectively. Thus, a direct relationship is observed between HBV genotype D and IDU and incarceration.

We found some similarities and differences between our results and previous reports by Panessa et al. from British Colombia, Canada and Fisker et al. from Denmark who had shown that despite the dominance of hepatitis $\mathrm{B}$ genotype $\mathrm{B}$ or $\mathrm{C}$ in Canadian and Danish general population, genotype $\mathrm{D}$ was observed in incarcerated IDUs ( $\mathrm{P}$ $=0.00025 ; \mathrm{P}=0.0067$ respectively) $(28,29)$. Accordingly, there was a similarity between these results and our findings which showed a positive relationship between genotype D and IDU and previous incarceration. 
Salem F et al.

Figure 2. Phylogenetic Tree
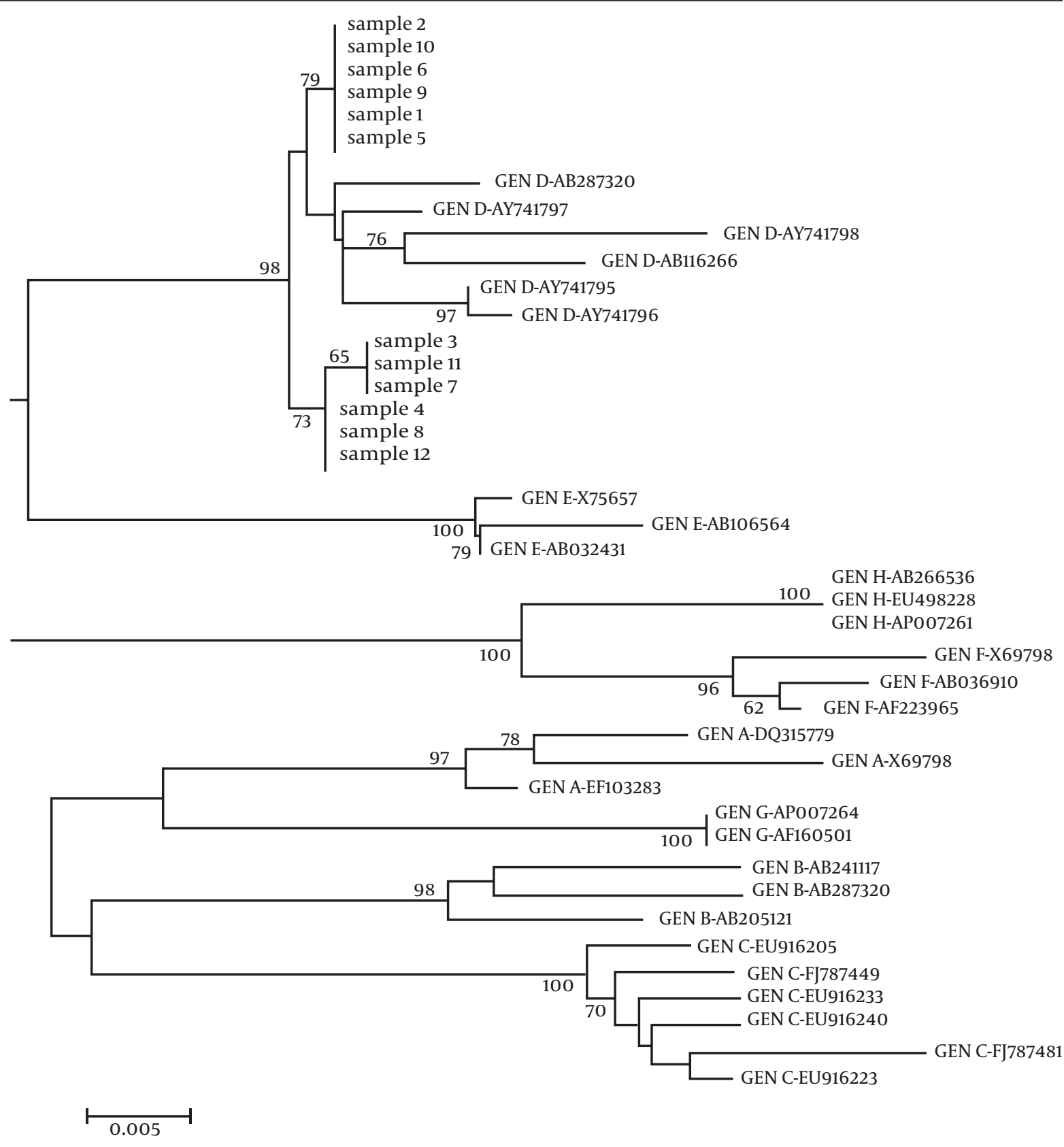

The tree was constructed using S ORF (585 bp) by the Neighbor Joining ( $\mathrm{N}-\mathrm{J})$ method and Kimura two parameter matrix with 1000 bootstrap resampling.

In contrast to Panessa et al. and Fisker et al. findings, in our study, we didn't find any differences between the HBV genotype of the general population (10) and incarcerated IDUs and the only genotype in Iran was genotype D.

As this study showed, incarceration is an important factor for transmission of HBV-D. International center for prison studies (ICPS), during October 2011, reported that there were about 250,000 prisoners in Iran. The number of prisoners has been increasing by approximately 200 - 300 persons per year (30). Finally, most of these prisoners return to the community and according to our study more than $75.3 \%$ of them have a history of drug injection. Indeed, IDU is the reason behind HBV genotype D epidemic in this country. Ministry of Health is serious about controlling hepatitis B in Iran. In this manner we 
need to pay more attention to risk factors for designing the best strategies to control the disease in the future (5). Therefore, performing free of charge vaccination for unvaccinated prisoners is suggested to further scale down HBV transmission. Finally, we conclude that IDU, as the greatest risk factor, may have the leading role in the presence of genotype D. However, this conclusion needs more scrutiny by researchers in the future to find the correlation between genetic diversity of hepatitis B virus and risk factors.

\section{Acknowledgements}

The investigators would like to thank all health personnel of Ghezel Hesar, Rajaii Shahr and Nedamatgah Karaj prisons who helped with the collection of samples.

\section{Authors' Contribution}

None declared.

\section{Financial Disclosure}

None declared.

\section{Funding/Support}

This study was supported by the Pasteur Institute of Iran.

\section{References}

1. Mackie CO, Buxton JA, Tadwalkar S, Patrick DM. Hepatitis B immunization strategies: timing is everything. CMAJ. 2009;180(2):196202.

2. World Health Organization . Hepatitis B. Available from: http// www.who/int/medicenter/factsheets/fs2 04/en/.

3. Alavian SM, Fallahian F, Lankarani KB. The changing epidemiology of viral hepatitis B in Iran. J Gastrointestin Liver Dis. 2007;16(4):403-6.

4. Alavian SM. Ministry of Health in Iran is serious about controlling hepatitis B. Hepat Mon. 2007;7(1):3-5.

5. Alavian SM. On the occasion of the world hepatitis day: world hepatitis day and our achievements and responsibilities in iran. Int J Prev Med. 2012;3(7):437-9.

6. Kramvis A, Kew M, Francois G. Hepatitis B virus genotypes. Vac cine. 2005;23(19):2409-23.

7. Tran TT, Trinh TN, Abe K. New complex recombinant genotype of hepatitis B virus identified in Vietnam. J Virol. 2008;82(11):565763.

8. Tatematsu K, Tanaka Y, Kurbanov F, Sugauchi F, Mano S, Maeshiro $\mathrm{T}$, et al. A genetic variant of hepatitis $\mathrm{B}$ virus divergent from known human and ape genotypes isolated from a Japanese patient and provisionally assigned to new genotype J. J Virol. 2009;83(20):10538-47.

9. Kao JH, Chen PJ, Lai MY, Chen DS. Hepatitis B genotypes correlate with clinical outcomes in patients with chronic hepatitis B. Gastroenterology. 2000;118(3):554-9.

10. Amini-Bavil-Olyaee S, Sarrami-Forooshani R, Adeli A, Sabahi F, Abachi M, Azizi M, et al. Complete genomic sequence and phylogenetic relatedness of hepatitis B virus isolates from Iran. J Med Virol. 2005;76(3):318-26.
11. Mir-Nasseri MM, Mohammadkhani A, Tavakkoli H, Ansari E, Poustchi $\mathrm{H}$. Incarceration is a major risk factor for blood-borne infection among intravenous drug users: Incarceration and blood borne infection among intravenous drug users. Hepat Mon. 2011;11(1):19-22.

12. Javadi AA, Avijgan M, Hafizi M. Prevalence of HBV and HCV infections and associated risk factors in addict prisoners. Iranian Public Health. 2006;35(4)

13. Weild AR, Gill ON, Bennett D, Livingstone SJ, Parry JV, Curran L. Prevalence of HIV, hepatitis $\mathrm{B}$, and hepatitis $\mathrm{C}$ antibodies in prisoners in England and Wales: a national survey. Commun Dis Public Health. 2000;3(2):121-6.

14. Decker MD, Vaughn WK, Brodie JS, Hutcheson RH, Jr, Schaffner W. Seroepidemiology of hepatitis B in Tennessee prisoners. J Infect Dis. 1984;150(3):450-9.

15. Allwright S, Bradley F, Long J, Barry J, Thornton L, Parry JV. Prevalence of antibodies to hepatitis B, hepatitis C, and HIV and risk factors in Irish prisoners: results of a national cross sectional survey. BMJ. 2000;321(7253):78-82.

16. Razzaghi EM, Movaghar AR, Green TC, Khoshnood K. Profiles of risk: a qualitative study of injecting drug users in Tehran, Iran. Harm Reduct J. 2006;3:12.

17. Alavian SM, Keyvani H, Rezai M, Ashayeri N, Sadeghi HM. Preliminary report of hepatitis B virus genotype prevalence in Iran. World J Gastroenterol. 2006;12(32):5211-3.

18. Zeng GB, Wen SJ, Wang ZH, Yan L, Sun J, Hou JL. A novel hepatitis $B$ virus genotyping system by using restriction fragment length polymorphism patterns of S gene amplicons. World J Gastroenterol. 2004;10(21):3132-6.

19. Kimura M. A simple method for estimating evolutionary rates of base substitutions through comparative studies of nucleotide sequences. J Mol Evol.1980;16(2):111-20.

20. Saitou N, Nei M. The neighbor-joining method: a new method for reconstructing phylogenetic trees. Mol Biol Evol. 1987;4(4):40625.

21. Kumar S, Tamura K, Nei M. MEGA3: Integrated software for Molecular Evolutionary Genetics Analysis and sequence alignment. Brief Bioinform. 2004;5(2):150-63.

22. Nelson PK, Mathers BM, Cowie B, Hagan H, Des Jarlais D, Horyniak D, et al. Global epidemiology of hepatitis B and hepatitis $C$ in people who inject drugs: results of systematic reviews. Lancet. 2011;378(9791):571-83.

23. Hou J, Liu Z, Gu F. Epidemiology and Prevention of Hepatitis B Virus Infection. Int J Med Sci. 2005;2(1):50-57.

24. Sofian M, Aghakhani A, Banifazl M, Azadmanesh K, Farazi AA, McFarland W, et al. Viral hepatitis and HIV infection among injection drug users in a central Iranian City. J Addict Med. 2012;6(4):292-6.

25. Kidd-Ljunggren K, Myhre E, Blackberg J. Clinical and serological variation between patients infected with different Hepatitis B virus genotypes. J Clin Microbiol. 2004;42(12):5837-41.

26. Clements CJ, Coghlan B, Creati M, Locarnini S, Tedder RS, Torresi J. Global control of hepatitis B virus: does treatment-induced antigenic change affect immunization? Bull World Health Organ. 2010;88(1):66-73.

27. Norder H, Courouce AM, Coursaget P, Echevarria JM, Lee SD, Mushahwar IK, et al. Genetic diversity of hepatitis B virus strains derived worldwide: genotypes, subgenotypes, and HBsAg subtypes. Intervirology. 2004;47(6):289-309.

28. Panessa C, Hill WD, Giles E, Yu A, Harvard S, Butt G, et al. Genotype $\mathrm{D}$ amongst injection drug users with acute hepatitis $\mathrm{B}$ virus infection in British Columbia.J Viral Hepat. 2009;16(1):64-73.

29. Fisker N, Pedersen C, Lange M, Nguyen NT, Nguyen KT, Georgsen $\mathrm{J}$, et al. Molecular epidemiology of hepatitis B virus infections in Denmark. J Clin Virol. 2004;31(1):46-52.

30. International centre for prison studies . World prison brief Available from: http://www.prisonstudies.org. 